\title{
The effect of aerosol ipratropium bromide and salbutamol on exercise tolerance in chronic bronchitis
}

\author{
A G LEITCH, J M HOPKIN, D A ELLIS, SYLVIA MERCHANT, AND G J R McHARDY \\ From the Department of Respiratory Diseases, University of Edinburgh, City Hospital, Edinburgh, UK
}

Leitch, A G, Hopkin, J M, Ellis, D A, Merchant, S, and McHardy, G J R (1978). Thorax, 33, 711-713. The effect of aerosol ipratropium bromide on salbutamol on exercise tolerance in chronic bronchitis. In a double-blind placebo controlled trial in 24 patients fulfilling the MRC criteria for chronic bronchitis, ipratropium bromide $40 \mu \mathrm{g}$ and salbutamol $200 \mu \mathrm{g}$ produced similar and significant $(\mathrm{P}<0.001)$ increases in forced expiratory volume in one second $\left(\mathrm{FEV}_{1}\right)$ and forced vital capacity (FVC). A greater increase in $\mathrm{FEV}_{1}$ and $\mathrm{FVC}$ was seen when both drugs were used together, but this increase did not differ significantly from that produced by either drug alone. Salbutamol increased the 12 -minute walking distance significantly $(\mathbf{P}<0.001)$ by $62 \pm 15$ metres, whereas the increase of $43 \pm 15$ metres observed after ipratropium was not significant $(P>0.05)$. With both drugs in combination 12-minute walking distance increased by $72 \pm 15$ metres, but this change was not significantly different from that observed with salbutamol alone. If aerosol bronchodilators in the doses used in this study are to be given with a view to improving exercise tolerance in such patients then salbutamol would appear to be the aerosol of choice.

Most workers have found that ipratropium bromide and $\beta$-adrenergic agents given by inhalation are equally effective in relieving airways obstruction in patients with chronic bronchitis and have found no additional benefit from simultaneous administration of the drugs (Gutersohn et al, 1975; Hertz and Strietzel, 1975; Petrie and Palmer, 1975; Poppius and Salorinne, 1975).

Recently, it has been suggested (McGavin et al, $1976 ; 1977)$ that the 12-minute walking distance (12 MD) may be a more sensitive index of disability in patients with chronic bronchitis than measurements of forced expiratory volume in one second $\left(\mathrm{FEV}_{1}\right)$ or other indices of airways obstruction. We have therefore compared the effects of ipratropium and salbutamol, singly and combined, on $\mathrm{FEV}_{1}$, forced vital capacity (FVC), and $12 \mathrm{MD}$ in chronic bronchitic patients in a doubleblind placebo controlled study.

\section{Patients and methods}

We studied 24 patients who fulfilled the MRC criteria for chronic bronchitis (Medical Research Council Working Party, 1965) (table 1). All had been or were heavy cigarette smokers, none had
Table 1 Characteristics of the 24 patients studied (20 men, 4 women)

\begin{tabular}{lcc}
\hline & Mean & Range \\
\hline Age (years) & $62 \cdot 5$ & $47-69$ \\
Height (cm) & 173 & $145-182$ \\
Weight (kg) & 64 & $40-89$ \\
FEV $(\mathrm{ml})$ & 828 & $280-1700$ \\
FVC $(\mathrm{ml})$ & 2311 & $430-3800$ \\
12 MD & 876 & $125-1460$ \\
\hline
\end{tabular}

peripheral blood eosinophilia, and patients with positive skin tests to common allergens were excluded. Patients who had angina, intermittent claudication, or a locomotor disorder were also excluded. Bronchodilator agents and disodium cromoglycate were withheld for 12 hours before the studies. We measured $F E V_{1}$ and FVC on a low resistance spirometer (McKerrow et al, 1960) taking the best of three readings (Freedman and Prowse, 1966) and the $12 \mathrm{MD}$ (McGavin et al, 1976). Subjective estimates of disability were recorded on the Borg Scale (Borg, 1962) and from the point marked by the patients on a structured diagram of everyday activities scaled in proportion to their oxygen cost. 
Table 2 Mean values $\pm S E M$ for $F E V_{1}, F V C$, and $12 M D$ in 24 patients before treatment and the mean values $\pm S E M$ for change in $F E V_{1}, F V C$, and $12 M D$ after treatment

\begin{tabular}{|c|c|c|c|c|c|c|}
\hline Treatment & $\begin{array}{l}12 M D \\
\text { Before } \\
\text { (metres) }\end{array}$ & $\begin{array}{l}\text { Change in } \\
12 M D \\
\text { (metres) }\end{array}$ & $\begin{array}{l}\text { FEV } \\
\text { Before } \\
(m l)\end{array}$ & $\begin{array}{l}\text { Change in } \\
F E V_{1} \\
(m l)\end{array}$ & $\begin{array}{l}\text { FVC } \\
\text { Before } \\
(m l)\end{array}$ & $\begin{array}{l}\text { Change in } \\
\text { FVC } \\
(m l)\end{array}$ \\
\hline $\begin{array}{l}\text { (A) Double placebo } \\
\text { (B) Salbutamol + placebo } \\
\text { (C) Placebo + ipratropium } \\
\text { (D) Salbutamol + ipratropium }\end{array}$ & $\begin{array}{l}880 \pm 15 \\
871 \pm 15 \\
888 \pm 15 \\
866 \pm 15\end{array}$ & $\begin{array}{l}4 \pm 15 \\
62 \pm 15^{* *} \\
43 \pm 15 \\
72 \pm 15^{* *}\end{array}$ & $\begin{array}{l}826 \pm 21 \\
822 \pm 21 \\
857 \pm 21 \\
807 \pm 21\end{array}$ & $\begin{array}{l}18 \pm 21 \\
148 \pm 21^{* * *} \\
146 \pm 21^{* * *} \\
204 \pm 21^{* * *}\end{array}$ & $\begin{array}{l}2299 \pm 51 \\
2303 \pm 51 \\
2341 \pm 51 \\
2299 \pm 51\end{array}$ & $\begin{array}{l}109 \pm 52 \\
410 \pm 52^{* * *} \\
448 \pm 52^{* * *} \\
503 \pm 52^{* * *}\end{array}$ \\
\hline
\end{tabular}

Changes after active treatments compared with the change after placebo. The results of these significance tests are ${ }^{* *} \mathrm{P}<0.01,{ }^{* * *} \mathrm{P}<0.001$.

We studied the patients on five consecutive days. On the first day we measured 12 MD on two occasions to accustom the patient to the test and to exclude training effects (McGavin et al, 1976). On each of the other four days the patients received on a double-blind basis one of the four following treatments, according to a Latin square design and administered by identical pressurised aerosols: (a) placebo+placebo; (b) salbutamol $200 \mu \mathrm{g}$ + placebo; (c) placebo +ipratropium $40 \mu \mathrm{g}$; and $(d)$ salbutamol $200 \mu \mathrm{g}+$ ipratropium $40 \mu \mathrm{g}$.

We measured FEV $_{1}$ and FVC 15 minutes after the first aerosol and then the second aerosol was given. We repeated measurements of $\mathrm{FEV}_{1}$ and FVC one hour after the second inhalation and then remeasured $12 \mathrm{MD}$. We calculated analyses of variance that used the Latin square design of the trial. This enables unbiased comparisons between treatments to be made. These analyses are briefly summarised in table 2 , and the results of significance tests among the treatment means are indicated by asterisks.

We also calculated correlation coefficients for $12 \mathrm{MD}$ with $\mathrm{FEV}_{1}, \mathrm{FVC}$, subjective estimate of disability, and perceived exertion on the Borg Scale before treatment with placebo in the 23 subjects.

\section{Results}

The results are summarised in table 2 . There were no significant differences at the $5 \%$ level between the baseline values for $\mathrm{FEV}_{1}, \mathrm{FVC}$, and 12 MD before each treatment.

For both $\mathrm{FEV}_{1}$ and FVC the mean increase in measurement after treatment was substantially greater after all active treatments than after placebo. For each comparison with the placebo the $t$ statistic was highly significant $(\mathrm{P}<0.001)$. The results for $12 \mathrm{MD}$ show the same general pattern. The changes in $12 \mathrm{MD}$ after salbutamol alone and in combination with ipratropium were significantly greater than that after placebo $(\mathrm{P}<0.01)$. The change in $12 \mathrm{MD}$ after ipratropium, however, was not large enough compared with the change after placebo to be statistically significant at the $5 \%$ level. Although treatment with both salbutamol and ipratropium is associated with the largest increase for $12 \mathrm{MD}, \mathrm{FEV}_{1}$ and FVC, it is not significantly larger than after either drug alone (ie $\mathbf{P}>0.05$ ).

Of the measurements made before treatment with placebo, $12 \mathrm{MD}$ correlated better with FVC $(r=0.6764)$ and $\mathrm{FEV}_{1}(\mathrm{r}=0.5278) .12 \mathrm{MD}$ correlated best with subjective estimate of disability $(r=0.7818)$ and was negatively correlated with perceived exertion on the Borg Scale $(r=-0.6050)$.

\section{Discussion}

The strong correlation of the $12 \mathrm{MD}$ with the subjective estimate of disability and weaker correlation with $\mathrm{FEV}_{1}$ found in this study confirm other findings (McGavin et al, 1977) and reinforce the belief that in chronic bronchitic patients the $12 \mathrm{MD}$ is a better index of disability than the FEV

The changes in $\mathrm{FEV}_{1}, \mathrm{FVC}$, and $12 \mathrm{MD}$ after drugs were recorded at a time when the bronchodilator effects of both drugs reached a maximum (Poppius and Salorinne, 1973; Petrie and Palmer, 1975; Storms and Reed, 1975). The doses used were chosen on the basis of previous work showing maximum bronchodilatation at these doses without side effects. Larger doses of ipratropium prolong the duration of action without a further significant increase in $\mathrm{FEV}_{1}$ (Alliott et al, 1972; N Storms and Reed, 1975). Our results do not suggest $N$ a close correlation between $\mathrm{FEV}_{1}$ and $12 \mathrm{MD}$. N Larger doses of the drugs used might therefore $\omega$ have produced further improvement in $12 \mathrm{MD}$, but in this study we chose to use commercially available preparations in standard dosage. The $\stackrel{\oplus}{\oplus}$ changes in $\mathrm{FEV}_{1}$ and FVC observed after sal-? butamol alone and ipratropium alone were similar. Both drugs in combination produced a greater $\frac{\overrightarrow{\mathbb{D}}}{\mathrm{D}}$

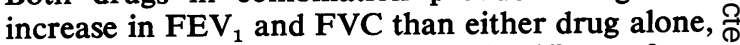
but this change was not significantly different from 음 the change observed with either drug alone, confirming the findings of Petrie and Palmer (1975). 
With both treatments containing salbutamol significant increases in 12 MD were recorded, but the increase observed with ipratropium alone was not significant at the $5 \%$ level. The absence of a significant increase in $12 \mathrm{MD}$ with ipratropium when the changes in $\mathrm{FEV}_{1}$ and FVC were virtually identical to those observed after salbutamol is not easily explained. Our findings would suggest, however, that if aerosol bronchodilators in conventional dosage are to be administered to improve exercise tolerance in patients with chronic bronchitis then salbutamol is the drug of choice.

We thank Mrs M V Shotter for statistical help.

\section{References}

Alliott, R J, Lang, B D, Rawson, D R W, and Leckie, W J H (1972). Effects of salbutamol and isoprenaline/phenylephrine in reversible airways obstruction. British Medical Journal, 1, 539-542.

Borg, G (1970). Perceived exertion as an indicator of somatic stress. Scandinavian Journal of Rehabilitation Medicine, 2, 92-98.

Freedman, S, and Prowse, K (1966). How many blows make an $\mathrm{FEV}_{1}$ ? Lancet, 2, 618-619.

Gutersohn, J, Joos, H, and Herzog, H (1975). The effect on Raw of Sch 1000 MDI or fenoterol MDI and the combined administration of subthreshold dosages of both compounds. Postgraduate Medical Journal, supp 7, 51, 113-114.

Hertz, C W, and Strietzel, G (1975). A comparison of effects on total airways resistance $(\mathrm{Rt}), \mathrm{FEV}_{1}$ and residual volume (RV) of Sch 1000 with fenoterol and placebo given as MDI. Postgraduate Medical Journal, supp 7, 51, 114.
McGavin, C R, Gupta, S P, and McHardy, G J R (1976). Twelve-minute walking test for assessing disability in chronic bronchitis. British Medical Journal, 1, 822-823.

McGavin, C R, Artvinli, M, Naoe, H, and McHardy, G J R (1977). Twelve-minute walking distance, spirometric measurements, and subjective estimates of disability in patients with obstructive and restrictive ventilatory defects. Thorax, 32, 648 .

McKerrow, C B, McDermott, M, and Gilson, J C (1960). A spirometer for measuring the forced expiratory volume with a simple calibrating device. Lancet, 1, 149-151.

Medical Research Council (1965). Definition and classification of chronic bronchitis for clinical and epidemiological purposes (Report to the Medical Research Council by their Committee on the Aetiology of Chronic Bronchitis). Lancet, 1, 775779.

Petrie, G R, and Palmer, K N V (1975). Comparison of aerosol ipratropium bromide and salbutamol in chronic bronchitis and asthma. British Medical Journal, 1, 430-432.

Poppius, H, and Salorinne, Y (1973). Comparative trial of a new anticholinergic bronchodilator, Sch 1000 , and salbutamol in chronic bronchitis. British Medical Journal, 4, 134-136.

Poppius, H, and Salorinne, Y (1975). Comparative trial of Sch 1000 MDI and salbutamol in patients with chronic bronchitis. Postgraduate Medical Journal, supp 7, 51, 118.

Storms, W W, and Reed, C E (1975). Dose-titration study of Sch 1000 MDI in comparison with isoprenaline. Postgraduate Medical Journal, supp 7, 51, 99-100.

Requests for reprints to: $\operatorname{Dr} R$ McHardy, City Hospital, Greenbank Drive, Edinburgh EH10 5SB. 